\title{
OF SLAVEHOLDERS AND RENEGADES: SEMANTIC UNCERTAINTIES IN VOLODYMYR ANTONOVYCH'S CONVERSION TO UKRAINIANNESS
}

\begin{abstract}
In an article published in the St. Petersburg-based Ukrainian language journal Osnova (Foundation) in 1862, Włodzimierz Antonowicz, formally the descendant of a Polish family from the landed gentry in Ukraine, declared that from then on he would consider himself a Ukrainian. In the present essay, I analyze the polemics around what can be called Antonovych's conversion from Polishness to Ukrainianness. Antonovych as well as his adversaries brought into play various concepts of nationality and national identity, switching quite freely between various frames of references (political thought of the Enlightenment and the Romantic era, contemporary historical fiction, and historiography).
\end{abstract}

Key words: $19^{\text {th }}$ century Ukraine; populism; nation-building; linguistic nationalism; Volodymyr Antonovych

\section{PANOWIE I RENEGACI: SEMANTYCZNE NIUANSE KONWERSJI WLODZIMIERZA ANTONOWICZA NA UKRAIŃSKOŚĆ}

\section{Streszczenie}

W artykule opublikowanym w 1862 roku w petersburskim ukraińskojęzycznym dzienniku "Osnova” Włodzimierz Antonowicz, formalnie potomek polskiej rodziny ziemiańskiej z Ukrainy, oświadczył, że od tego momentu będzie siebie uznawał za Ukraińca. Autor eseju analizuje polemikę wokół tego, co można nazwać konwersją Antonowicza od polskości
JENS HERLTH University of Fribourg, Fribourg, Switzerland E-mail: jens.herlth@unifr.ch

CITATION: Herlth, J. (2017). Of Slaveholders and Renegades: Semantic Uncertainties in Volodymyr Antonovych's Conversion to Ukrainianness. Sprawy Narodowościowe. Seria nowa, 2017(49). https://doi.org/10.11649/sn.1305

This work was supported by the author's own resources. No competing interests have been declared.

This is an Open Access article distributed under the terms of the Creative Commons Attribution 3.0 PL License (creativecommons.org/licenses/by/3.0/pl/), which permits redistribution, commercial and non-commercial, provided that the article is properly cited. (C) The Author(s) 2017.

Publisher: Institute of Slavic Studies, Polish Academy of Sciences 
do ukraińskości. Antonowicz, podobnie jak jego adwersarze, posługiwał się różnymi koncepcjami narodowości i tożsamości narodowej, dość swobodnie przechodząc do odmiennych odniesień w myśli politycznej (Oświecenia i epoki romantyzmu, współczesnej prozie historycznej i historiografii).

Słowa kIuczowe: Ukraina XIX wieku; populizm; budowanie narodu; nacjonalizm językowy; Włodzimierz Antonowicz

Y es, Mr. Padalica, you are right! I really am a renegade," Volodymyr Antonovych (1834-1908) wrote in an article published in 1862 in the St. Petersburg based journal Ukrainian Osnova (Foundation). This sentence was the culminating point in a polemic between Antonovych and the Polish journalist and writer Zenon Fisz (18201870) whose pen-name was Tadeusz Padalica. Antonovych had first studied medicine and then, after some months of doing his practice in the Ukrainian provinces, returned to Kiev University and received his diploma in history in 1860 (Ul'ianovs'ky̆, 1995, p. 25). Later he became a famous historian and is widely considered one of the founding fathers of Ukrainian historiography (Kvid, 1999, p. 373); one of his disciples was Mykhailo Khrushevs'kyi (Plokhy, 2005, p. 6). Antonovych was a descendant of the Polish landed gentry; at the time of the dispute with Padalica, Antonovych was a teacher of history at the Kievian Cadet Corps (Liaskoronskiĭ, 1908, p. 57). But earlier as a student, he was a member of a Polish students' association (Doroshenko, 1942, p. 17) and an enthusiastic supporter of the Polish cause (Miiakovs'ky̆, 1923, p. 234). Yet while the Polish student circles at the Imperial University of Kiev became more and more involved in conspiratorial activity, preparing for what was to become the January Uprising of 1863, Antonovych had committed himself to the fate of the peasantry of Right-Bank Ukraine. In 1860, he broke with his Polish background, family traditions, the circles of Polish nobility, and created an association of khlopomany ("lovers of the peasantry") in Kiev (Hillis, 2012, pp. 308-309; Kvid, 1999, p. 374); additionally, according to some sources, he converted to Orthodoxy (Adamski, 2008, p. 64; Doroshenko, 1942, p. 19; Ul'ianovs'kyı̆, 1995, p. 25). Antonovych's article in Osnova was programmatically entitled "My Confession," and it was in this article that he unambiguously proclaimed his break with his Polish background and his new allegiance to the Ukrainian camp.

In many ways the early 1860s was a crucial period in the history of the Russian Empire. The disaster of the Crimean War triggered debates about necessary reforms; Alexander II's ascension to the throne in 1855 had aroused hopes for a certain liberalization in state and society; and the liberation of the serfs in 1861 was a change of far-reaching importance for Russian society. The dispute between Antonovych and Padalica along with the articles and public letters that preceded it must be seen in this framework of an empire on the eve of fundamental reorganization with social and national interests of centrifugal and centripetal tendencies overlapping and competing with each other.

In what follows I will analyze the polemics around what can be called Antonovych's "conversion" from Polishness to Ukrainianness. From today's point of view, it is of course impossible to track the actual motivations of Antonovych's decision. However, his own explanations as well as his adversaries' reactions and various comments in the memories of contemporaries will allow me to reconstruct an extremely variable field of possibilities in which concepts of nationality and national identity were very much open to interpretation and negotiation. The openness of this disparate field is reflected in the very 
existence of Osnova, which was a forum for Ukrainian thought, folklore, literature, and linguistics. Using contemporary terminology, one could best describe its central concerns as those of nation-building and identity-construction (for a discussion of the journal's program see: Miller, 2003, pp. 75-79); although both of these targets were obviously articulated in a rather cautious manner with regard to censorship and the sensitivity of the political authorities in the Tsarist Empire when matters of ethnicity and nationality were concerned. The journal was founded and run by renowned Ukrainian intellectuals, such as Vasyl Bilozersky, Panteleimon Kulish, Mykola Kostomarov, and others ("Osnova (Saint Petersburg)," n.d.). Although only twenty-two issues were published between 1861 and 1862, this bilingual periodical, written in Russian and Ukrainian, was an important landmark in the shaping of a Ukrainian national identity.

\section{PLANTATION OWNERS IN THE UKRAINIAN PROVINCES}

In "My Confession," Antonovych writes that "destiny had it," that he was born in Ukraine as a member of the Polish landed gentry (Antonovych, 1862, p. 94): "In my childhood I had all the habits of the landowners and for a long time I shared all the social and national prejudices of the people with whom I grew up" (p. 94). He points out that at least in his own biographical experience, Polishness was nothing more than a certain register of norms, habits, values, and modes of conduct that were inextricably linked to the estate of the szlachta. The pure contingency of this identity on the one hand and its reduction to a set of norms on the other make it all the more easier for him to dissociate himself from this background. It is essential to see that Antonovych's words do not imply what we could call a deconstruction of Polish national identity in general. He is in fact-at least partly, as we will see-a proponent of romanticist and essentialist ideas of the nation; however, in the specific framework of Right-Bank Ukraine, Polish national identity has no arguments on its side, according to Antonovych. There are, according to him, no historical or linguistic data that could prove the legitimacy of a Polish presence in this part of the Empire (Antonovych, 1862, p. 87).

At a certain point, Antonovych developed a certain "self-awareness" and, when assessing "cold-bloodedly" his situation in country and society, he had to understand that, from a moral point of view, he found himself at a dead-end. There were two options for him: Either he could "rehouse" himself to the Polish lands or he could definitely renounce to the Polish szlachta, an "estate" (kasta), as he put it, of "settlers and plantation owners" (Antonovych, 1862, p. 94). This last option would be tantamount to approaching the "Ukrainian people" (Antonovych, 1862, p. 94).

Antonovych's passage to the "south-Russian" or "Ukrainian" (Antonovych, 1862, p. 89) camp was the result of moral considerations. He understood his own case as being representative for all Poles living in the Ukrainian part of the empire. His public "Confession" was meant to serve as an example showing the way out of the dead-end in which the members of the szlachta found themselves. That is why he was very much concerned about sincerity and why, several times throughout his article, he reproaches his adversary of hypocrisy and dishonesty, or "pritvorstvo" in his words. Speaking about Padalica's way of presenting historical and political facts, Antonovych uses such terms as "tactics," "sophism," "syllogism." In his outlining of Ukrainian-Polish relations he resorts 
to the semantic field of ambiguity and logical inversion, the key term being "pereverten'" (renegade). Antonovych had borrowed it from an "Open Letter" that Padalica had addressed to the journal Osnova and to which "My Confession" is the response.

The leitmotif of the dispute is a proverbial expression which Antonovych had quoted in an article in an earlier issue of Osnova - Padalica's "Open Letter" was the reaction to this article. The expression is: "Брехнею світь перейдешь, та назадъ не вернесся" [sic] (Antonovych, 1861, p. 11). One could translate it as "A lie will get you all the way to the end of the earth, but it will not bring you back." This, of course, can be referred to the whole moral and historical situation of the Polish szlachta as depicted in "My Confession." In his earlier article Antonovych dealt more specifically with the Polish writer Marian Gorzkowski's assessment of the historical role of Bohdan Khmelnytsky and Ukrainian history in general, as documented in an anonymous remark that was published in the "Literary News" section of the journal Biblioteka Warszawska (Warsaw Library) in early 1861. "The goal of the author is praiseworthy," we can read about Gorzkowski's latest publications: "He wants to reconcile the Ruthenian peasants with the Polish gentry." And furthermore, we read that, earlier, Gorzkowski had sent some "excerpts from the Vatican archive" which were meant to prove that Khmelnytsky, who the "Little Russian writers have made their national hero," was in fact nothing more than a "brigand chief" (Wiadomości Literackie, 1861, p. 252). This was unacceptable for Antonovych, as was also the coverage of the celebrations on the occasion of the transfer of the remains of Taras Shevchenko from St. Petersburg to the Ukrainian village of Kaniv in May 1861 in the Warsaw daily Gazeta Polska of the celebrations on the occasion of the transfer of the remains of Taras Shevchenko from St. Petersburg to the Ukrainian village of Kaniv in May 1861. Shevchenko, who died on March 10, was first buried in the capital, but then his corpse was exhumed and transferred to Kiev where a funeral service was held and his remains were subsequently brought to Kaniv for their final burial. The correspondent of the Gazeta Polska, which at the time was edited by the famous writer Józef Ignacy Kraszewski, had reported that a funeral service was held in a "Uniate Church" in Kiev (Gazeta Polska, (18618, June 1, No 137, p. 2).

Antonovych saw this as a deliberate misrepresentation of the facts, as every "inhabitant of the south-Russian lands" knew, there were no such churches in this region (Antonovych, 1861, p. 11). For him it was evident that the "Poles" were adapting Ukrainian realities according to their own political interest. He even saw this as a "deliberate untruth, born by the hidden thought of Catholic proselytism," i.e., he reproached Kraszewski's newspaper for attempting to posthumously convert "the poet of our people" ("наш народный поэт"; Antonovych, 1861, p. 11) from Orthodoxy to Catholicism and, accordingly, from Ukrainianness to Polishness. All of which, he found, was deeply offensive "for us, the inhabitants of Ukraine" (Antonovych, 1861, p. 7).

We see that Antonovych, while implicitly declaring his adherence to the "people" of a certain territory and subtitling his article "A Letter to the Editor from Kiev," is above all concerned about the demarcation of a symbolic field. He builds Ukrainian national identity as opposed to Polish identity on the level of language, history, territory, religion, and, of course, literature, with Taras Shevchenko serving as the Ukrainian pendant to the Polish national poets and as the link between the community of the peasantry on the one hand and the circles of the intellectuals on the other. It was precisely in this sense that Kulish describes the historical role of Shevchenko in a contribution to "Osnova" shortly after the poet's dead (Kulish, 1980b). 
Antonovych tells his readers that he had already written a letter to the Gazeta Polska demanding a correction of the misleading facts. A short answer was then printed, in which the editor expressed his gratitude to a "Mister W. A. from Kiev," for correcting the minor mistakes in the covering of the celebrations, stating however that he cannot understand why it should have been so offensive for Shevchenko, if the service had in fact been held in a Uniate church. "This would in no way cast a shadow on the deceased, and anyway" (Gazeta Polska, 1861b). It was this last word "anyway" (owszem) together with the concession that "we do not all care so very much about the deceased that we are to that point concerned about the details" (Gazeta Polska, 1861, June 25, No 152, p. 4) which vexed Antonovych. He understood this as a deliberate denigration of Ukrainian culture-which it was probably meant to be. The Polish elites in Warsaw still seemed to claim a kind of interpretational sovereignty as far as standards and values in Ukrainian culture were concerned. So "Mister W. A. from Kiev" decided to bring the affair to the political center of the empire and attack the Warsaw journalists in the Petersburg Osnova. It is in this context that Antonovych quotes the proverb about the impossibility of going back by a lie, insinuating that the standpoint of the Polish nobility in Ukraine could not be defended.

In his reaction to Antonovych's complaint about historical falsities in the Polish press, "Pan Padalica" addressed his letter to Osnova, in which he turned the proverb against Antonovych himself, stating that one could indeed refer it to "every renegade" (до кожного перевертня) (Padalica, 1861, p. 141). The word he uses-pereverten'-is curious in many ways; first of all, because Padalica seems to follow a strategy adopted by Antonovych. He draws on popular mythology, or, the "imagined imaginary" of the Ukrainian people; the term pereverten' meaning "renegade" in a political sense but also referring to a mythical werewolf-like being that can switch between various appearances according to the situation. The word is present in Kulish's recently published historical sketch Khmel'nyshchyna, where the author depicts a seventeenth-century Ukrainian landowner who converted to Catholicism and "changed from a Rusyn to a Liakh" (зъ Русина Ляхомъ изробився) as "pereverten"' (Kulish, 1861, р. 59). Another important reference in this context is Shevchenko's poem "The Plundered Grave" (Rozryta mohyla) from 1843 in which he describes "renegades" (перевертні) helping the Muscovite to exploit Ukraine and its people (Shevchenko, 2003, p. 253).

Padalica's letter was written in Ukrainian and signed "from Ukraine" (Padalica, 1861, p. 141), whereas Antonovych's contributions to Osnova were written in Russian. Padalica was an intimate connoisseur of Ukrainian matters; by the time of his dispute with Antonovych, his expertise probably exceeded the latter's. He had published two volumes of Sketches from Travels in Ukraine (Padalica, 1856a) which contained not only historical and political considerations but also ethnographical observations from the life and everyday culture of the Ukrainian peasants such as oral histories, songs, and legends. He even had dealt with topics such as "How to collect sayings and songs from the lips of the people" (Padalica, 1856b, pp. 31-32).

Antonovych, who certainly was aware of Padalica's background, tried to compensate his own lack of expertise and credibility-he timidly declared that he was writing in Russian since he had learned it "better than Ukrainian" (Antonovych, 1862, p. 83)—by occasionally sprinkling Ukrainian expressions in the text of his "Confession." In fact, the linguistic level is of great importance in his line of arguments against the historical legitimacy of Polish rule over Right-Bank Ukraine. For him it was a fact that "the people" has 
always remained "faithful to its nationality" (Antonovych, 1862, p. 89) which can easily be proven by the language it uses (p. 87). "Listen to the language of the people," (p. 89) he recommends to Padalica, "to their popular songs and proverbs, and you will enter the living, original logic of any of your former serfs." This advice sounds a bit odd when we think of Padalica's published accounts of his travels through the Ukrainian provinces in which he more than once gives voice to the peasants he encounters on his way. But we are in the middle of a struggle for symbolic hegemony and in this struggle Antonovych resorts to the moral argument, presenting his adversary not as a writer or ethnographer of his own right, but as a former slaveholder.

Antonovych's love for the Ukrainian people, their language and their popular wisdom notwithstanding, we have to note that the maxim "A lie will get you to the end of the earth..." was not necessarily overheard by him during one of his trips through the Ukrainian countryside. He could as well have found it in Kulish's historical novel Chorna rada, khronika 1663 roku (The black council, chronicle of the year 1663), where the phrase is uttered by one of the Cossacks (Kulish, 1857, p. 378). Kulish was the first to write historical novels dealing with Ukrainian history and he was one of the editors of Osnova. Antonovych's folkloristic imagination and his populist ideas might have been nourished by contemporary historical fiction. Most possibly, we are dealing with a mutual enhancement between actual, so to say empirical, encounters with the peasantry during his "field work" and his readings in Ukranian historiography and historical fiction.

In his "Confession," Antonovych does yet another turn, declaring that he is indeed a renegade and proud of being one, "just as, in America, I would have been proud to change from a plantation owner to an abolitionist or in Italy from a papist to an honorable and hardworking servant of the national cause" (Antonovych, 1862, p. 95). The references are clear; he hints to the liberation for the serfs in the US and to the Italian Risorgimento. For him both political projects come together in contemporary Ukraine. In fact, the nation in itself is of secondary importance here, the priority being the realization of the moral laws that were violated by the situation in the Ukrainian countryside. In his Memoirs, which he worked on during the last years of his, life, i.e., in the beginning of the twentieth century, Antonovych wrote:

I do not belong to the class of the landowners, and my family memories are not linked to any piece of territory which I could call my nest and in which local or documentary memories of this or that activity of my ancestors would by preserved. (Antonovych, 1932, p. 4)

He also explains in his Memoirs that he owes his aversion to Polish traditions to the rude and brutal educational methods of his mother (deceased in 1855) who had worked as a governess in Polish gentry households in the Ukrainian provinces throughout her life. We read that she "was an ardent patriot" and that she was eager to pass this patriotism on to her son. Speaking of his patriotic education, Antonovych ridicules the basic canonical version of Polish national history that prevailed in the houses of the Polish nobility in the middle of the nineteenth century-everything which is your own is good, everything alien is evil, and "the Uprising of 1831 was talked about as if it were a sacred tradition" (Antonovych, 1932, p. 27). Even literary taste and knowledge in matters of literature testified to the low level of culture in this declining class of Polish gentry in the middle of the nineteenth century as seen by Antonovych. In his retrospective glance, the "chauvinist patriotism" and "catholic fanaticism," as well as the whole cluster of ideas that is generally called "Polish messianism" in Polish cultural history-Antonovych does not actually use the term, but rather reduces the concept to its constituent parts—serve only to cover 
up the factual lack of historical and moral legitimacy for the dominating position of the Polish gentry in the Ukrainian guberniyas of the empire (Antonovych, 1932, p. 36).

Of course, we have to take into account that these memories were written at the beginning of the twentieth century when it was obvious that the Polish nobles in the Ukrainian provinces of the mid-nineteenth century were indeed in a desperate situation for political, national, and economical reasons. A very similar account can be found in the memoirs of the Polish landowner Tadeusz Bobrowski written at the same time. Still the Polish Bobrowski stresses that other options could have been taken and that it was, above all, the outbreak and the fatal consequences of the January Uprising of 1863 that put an end to the Polish presence in Right-Bank Ukraine (Bobrowski, 1979, pp. 441, 504).

\section{ANTONOVYCH'S UNDERSTANDING OF NATIONALITY}

The overall criterion for a distinct nationality for Antonovych was very much in the spirit of romanticist ideas - language. In "My Confession," he attacks the Polish attempts at describing the Ruthenian language as a provincial dialect of the Polish language, mentioning specifically Feliks Żochowski, who in a then recent contribution for Biblioteka Warszawska, argues that the "Ruthenian" language was not a language in its full right since its scope was limited to everyday life and family conversation; it would surely not be capable to cover matters of "higher" complexity. Żochowski postulated a kind of diglossia between "low" Ruthenian and "high" Polish, while, for him, both languages were in fact organically linked one to another (1861, p. 669). The question of language was crucial for the contemporaries; alongside history it was an important source of legitimacy. Żochowski emphatically conjures the Ruthenian (not quite) language as a "body which is our common property, which is a bone of our bones, animated by the same breath of life" (p. 669). These organic and even religious metaphors serve to essentialize the link between the Polish and the Ukrainian components. Antonovych, insisting on the distinction between the two languages, was following more or less the same line of argumentation, however he came to different conclusions. He was not a linguist, or was he even able to write in the language he was so much concerned about, but this did not hinder him from referring to popular wisdom and to a specific knowledge which the Ukrainian peasants disposed of. For him it was obvious that the reflections of Polish observers concerning the linguistic situation in the Ukrainian provinces were highly biased; their interest was to show the genetic links between the peasants' dialects and the Polish standard language, thus fitting both idioms in a complementary model. For Antonovych, linguistic reality spoke a different language and the peasant's idiom, which he did not analyze from a systematic point of view, was self-evidently the expression of a specific non-Polish world-view and of specific, non-Polish (i.e., non-noble) social relations. We can assume that, prior to his acquaintance with the actual linguistic and ethnographic data he encountered on his travels, Antonovych already had a quite clear idea of what these data would tell him; they would have to confirm his political convictions of the unique role to be played by the peasantry. Clearly, the myth of the peasantry as a social and political agent was at the basis of Antonovych's observations concerning the Ukrainian language.

In his contributions to Osnova, he time and again quotes Ukrainian proverbs and sayings; he probably collected them on the extensive tours through the Ukrainian country- 
side that he undertook together with other khlopomany from Kiev University in the late 1850s: "We have come to the conclusion that it was a shame to live in a country and not to know the customs of the Ukrainian people, nor its language, its songs, its traditions" (Antonovych, 1932, p. 41), he explains in his Memoirs. In his argumentation he tries to construct a level of intimate familiarity with the concerns of the Ukrainian people that is not accessible to a "Pan" like Padalica.

However, apparently the linguistic argument was not enough on its own; there is also a strong component of populist ideology in Antonovych's line of thinking. The editors of Osnova were very aware of the symbolic play around the issues of language; in their short introduction preceding Padalica's response to Antonovych's first article, they explain that "Pan Padalica so fervently defends the cause of the gentry [свою панську сторону] that he even wrote his letter in our [language]"- "по-нашому, " as they put it (Padalica, 1861, p. 136). So language serves as a marker of identity and political allegiance, but it does not suffice to express oneself in Ukrainian in order to be taken serious by the Ukrainophiles in St. Petersburg (Kulish, Kostomarov, and others). For Antonovych, this meant that he could on the one hand treat language in the framework of an essentialist and ethnicist understanding of language-the existence of a distinct Ukrainian language serving as a guarantee for the existence of a distinct Ukrainian, and, above all, non-Polish ethnos-but he could on the other refer to the inclusive idea of the nation as developed by French Enlightenment philosophers. In this understanding national allegiance could well be based on choice.

The Polish noble Wacław Lasocki even in a way "repatriated" Antonovych and his fellow khlopomany in his Memoirs, stating that they were simply going back to the "tradition of the Four-Year-Sejm, of Kołtątaj, Staszyc, and Potocki" (Łasocki, 1933, p. 295). In his own Memoirs, Antonovych openly admitted that as a high school student in Odessa he did not know anything about Ukraine and did not even hear anything about the Brotherhood of Saints Cyril and Methodius (1932, p. 40), a secret society, which had been active in Kiev in the middle of the 1840s and in many ways had contributed to the articulation of modern Ukrainian national identity (Bilenky, 2012, pp. 287-291). Even the name of Shevchenko had been unknown to him at the time. He writes that during his youth in Odessa in the second half of the 1840s, he was under the influence of his biological father, Janosh/Ivan Dzhidai (Antonovych, 1932, pp. 5, 10) who held high the ideals of eighteenth century French philosophy. Young Włodzimierz read Montesquieu, Rousseau, and Voltaire "and the other encyclopedists" and formed his worldview by putting together his "feeble knowledge of Ukraine" and general ideas from French democratic theory (Antonovych, 1932, p. 40). Even when telling his own biography, Antonovych argues on two levels: The philosophical influence transmitted to him by Dzhidai is underpinned by the fact that the latter was not only his philosophical inspirer but also his biological begetter, not to forget that Dzhidai himself was the son of a Hungarian rebel and a Ruthenian peasant woman (Antonovych, 1932, p. 5). ${ }^{1}$

In Antonovych's autobiography, democratic theory clearly precedes its application: "I was wondering how I could apply on my ground the general principle of theoretic democracy. It turned out that, in my country, the democratic element was the peasant" (Antonovych, 1932, p. 40). This is how he describes his first steps in the process of becoming a Ukrainian. The farewell to Polishness and the adoption of a new nationality was

1 This information about Antonovych's family background is commonly taken for granted in scholarship, although the only reference available is his own autobiography. 
a highly conscious, so to say, a philosophical decision for Antonovych. Still this decision needed to be grounded, he and his fellow students travelled through all the gubernyias of Right-Bank Ukraine right to the coast of the Black Sea (Antonovych, 1932, p. 41) during three vacations. They were impressed by the "strong logic and the popular ethics" that they encountered in the Ukrainian people, by their readiness to help each other and their extraordinary generosity towards the travelling students (Antonovych, 1932, pp. 41-42). His acquaintance with the customs and habits of the Ukrainian people provided him a direct access to this somewhat mythic element that was the people; it became the incarnation of his philosophic considerations. Already in his "Confession," Antonovych is concerned about highlighting this romanticist strain. Speaking about his upbringing in the circles of the Polish gentry he says that

for me it was easier to bid them adieu [i.e., the "habits and dreams" of his noble education] than to the people, among whom I grew up, whom I knew, and whose bitter fate I had seen in every village, where they were owned by a noble-from whose lips I had heard more than one sad, heartbreaking song, more than one sincere, amicable word (even though I was a panich) [...], the people who, in short, I loved more than all the noble habits and reveries. (Antonovych, 1862, pp. 94-95)

Antonovych, his fellow khlopomany, but also the Polish noble Padalica/Fisz were all obsessed with the people and saw it as a source of mythical wisdom and historical, social, and moral knowledge. There was a regular section in "Osnova," entitled "From the People's Lips."

Antonovych describes the turning point in his biography as a shift from one camp to another, as a deliberate exchange of one national allegiance to another, and it was this rhetoric of conversion that nourished his own "Confession" as well as the attacks of his adversaries on the side of the Polish gentry who thought him as a traitor and renegade. However, things were not as easy and one-dimensional as it may have looked. In "My Confession," the confrontation between Polishness and Ukrainianness is not seen as confrontation between two nations, but instead as struggle between two conflicting social classes. This was important, since this understanding of the conflict as a primarily social one allowed the khlopomany to publicly refute allegations of separatism (Saunders, 1995, p. 44). According to Antonovych and other Ukrainophile intellectuals of the time, Polishness was tantamount to the gentry, which was in turn associated with the oppression of the Ukrainian peasantry in the past few centuries. On the other hand, the peasants stood for democracy, social development, and by this, the future.

Antonovych carefully manoeuvers between political and moral concepts of the nation on the one hand and essentialist understandings on the other, one element superposing and underpinning the other. As for the Polishness of the Polish nobility, he had one more essentialist argument at hand that served him to delegitimize the Polish cause. The contemporary Polish landowners in Ukraine were the descendants of former Ukrainian boyars, who, in the sixteenth century had adopted the Polish nationality, since the Polish "state of affairs" had offered them a convenient social order (Antonovych, 1862, p. 88). For him it was indisputable that the real renegades and traitors were those boyars from "Southern Russia," who once deliberately "polonized" themselves (ополячились; р. 88), what eventually led to the "identity between Pole and szlachcic" (p. 88). On an implicit level, we are led to conclude that Antonovych, the proud renegade, merely changes back to his real "south-Russian" identity. However, this argument served only to support the real, political reason for Antonovych's decision. Whereas the institution of the szlachta 
had been worked out by "Polish social life," the Ukrainian people sought what he called "social self-government" (общественное самоуправление; р. 88).

In practice, however, it was not by referring to his ancestry-or parental affiliations with the peasantry, or more remote connections with the Ukrainian boyarstvobut through "labor and love," that he hoped to merit some day to be accepted by the "Ukrainians as a son of their people" (Antonovych, 1862, p. 95). The discourse of nationality as we encounter it in Antonovych's "Confession," but also in the writings of other Ukrainophiles of the late 1850s and early 1860s, is very much one of emotional affection; the model for the nation was, after all, the "large family" of "kindred spirits" as Ukrainian people were conceived of by Kulish (1980a, p. 56), Antonovych, and others. It is not sufficient to be able to collect songs and legends from the peasants' lips, one must also be emotionally moved by his words, one must respect him as a human being and not compare him to a "bird who sings for himself," as had done Padalica in his Sketches, explaining how he collected popular songs and legends (1856b, p. 32).

\section{CONCLUSION}

In all of his discussions of the historical precedents of the current situation in Ukraine and of his own biography, Antonovych oscillates between the poles of essentialism and optionality. Although it is quite obvious that the political and moral considerations generally outweigh the romanticist and essentialist arguments, it is nevertheless quite telling that Antonovych performs what could be called a secondary essentialization of political choices and moral decisions, as if-at least for the sake of the polemic with his adversaries from the Polish nobility, but probably also in view of his standing in the community of the Ukrainophiles-he was in need of a more substantial foundation for his move.

Antonovych was in the middle of a laboratory of nation building and thanks to his emotional and intellectual detachment from his own milieu he disposed of a specific clearsightedness when it came to matters of inclusion and exclusion, of creating communities through references to history, language, and social habits. The imperial situation made it possible for him to opt for a "foreign" nationality, which was not foreign at all. One could even say, and Polish observers did so, that he must have understood that a new uprising was imminent and that it would help his career as a historian to position himself as a Ukrainian. But one must also understand that the question of nationality for him was really only a byproduct of the question of the social situation of the peasantry.

It should not surprise us that Antonovych's adversaries from the camp of the Polish gentry contested the very possibility of a choice in matters of nationality. While Antonovych had referred to the semantics of inversion, his antagonists worked more with the semantic field of masking and unmasking, thus demonizing their former compatriot's move. The figure of the pereverten' in its mythological meaning of werewolf was open to both readings. We should as well remember that the Polish political imaginary in matters of national allegiance and treason was shaped by Adam Mickiewicz's extremely influential narrative poem Konrad Wallenrod from 1828. It tells the story of a Lithuanian in the service of the Teutonic Order who carefully conceals his real origin until the very moment when, as a Great Master of the Order, he leads its troops to a disastrous defeat in a battle against the Lithuanians. Later, Lasocki will write in his Memoirs that "the ter- 
rifying events of the years 1861 to 1863 forced [Antonovych] to throw off his mask and to pursue the path of obvious national defection" (1933, p. 231), which, of course, is to state that Antonovych had carefully hidden his real identity right up to the moment of his conversion.

It is easy to detect, in Antonovych's "Confession," Memoirs, and also the reactions to his conversion a certain consciousness of the contingency of the category of the nation. "Nation" and "nationality" were not exclusively perceived as naturally given, which, however not only did not exclude, but paradoxically even generated attempts to re-naturalize them. This contingency is reflected by the semantic uncertainties we could encounter in Antonovych's own argumentation but also in the rhetoric of his adversaries. In Antonovych's understanding of nationality, language played a crucial role. He conceived of it as of an objective reality, lying at the foundations of the community of the people in its contemporary, social, as well as in its historical and imaginary dimension. At the same time, language was, of course, also a means to conceptualize social and political reality. It could serve to create symbols of identity, but it could as well invert and manipulate them. The imperial situation allowed for a certain range of options, but at the same time it reduced Antonovych's and his fellow Ukrainophiles' scope of action to the sphere of culture, which is why they focused on history, language, and literature, trying to develop, to demarcate, and defend the symbolic capital of the Ukrainian community.

\section{REFERENCES}

Adamski, Ł. (2008). Włodzimierz Antonowicz: Polski renegat czy Wallenrod z Kijowa. Włodzimierz czy Wołodymyr?: Za kogo uważał się profesor Antonowicz? Nowa Europa Wschodnia, 2008(2), 63-75.

Antonovych, V. (1861). Chto ob ètom dumat'?: Pis'mo k redaktoru iz Kieva (7 iiulia 1861). Osnova, 1861(7), 7-13.

Antonovych, V. (1862). Moia ispoved': Otvet Panu Padalitse. Osnova, 1862(1), 83-96.

Antonovych, V. (1932). Memuary. In V. Antonovych, Tvory (Vol. 1, pp. 3-65). Kyïv: Vseukraïns'ka akademiia nauk.

Bilenky, S. (2012). Romantic nationalism in Eastern Europe: Russian, Polish, and Ukrainian political imaginations. Stanford: Stanford University Press. https://doi.org/10.11126/ stanford/9780804778060.001.0001

Bobrowski, T. (1979). Pamiętnik mojego życia (S. Kieniewicz, Ed.) (Vol. 2). Warszawa: Państwowy Instytut Wydawniczy.

Doroshenko, D. (1942). Volodymyr Antonovych: Ioho zhyttia i naukova ta hromads'ka diial'nist'. Praha: Vydavnytstvo luriia Tyshchenka.

Hillis, F. (2012). Ukrainophile activism and imperial governance in Russia's southwestern borderlands. Kritika, 13(2), 301-326. https://doi.org/10.1353/kri.2012.0019

Kulish, P. (1857). Chorna rada: Chronika 1663 roku. St. Petersburg: Tip. Aleksandra lakobsona.

Kulish, P. (1861). Khmel'nyshchyna: Istorychnie opovidannia. St. Petersburg: P. A. Kulish.

Kulish, P. (1980a). Graveside oration. In G. S. N. Luckyj (Ed.), Shevchenko and the critics, 1861-1980 (pp. 55-56). Toronto: Toronto University Press. 
Kulish, P. (1980b). Why Shevchenko is a poet of our people. In G. S. N. Luckyj (Ed.), Shevchenko and the critics, 1861-1980 (pp. 57-64). Toronto: Toronto University Press.

Kvid, B. (1999). Volodymyr Antonovych: Ukrainian populist historiography and the cultural politics of nation building. In T. Sanders (Ed.), Historiography of Imperial Russia (pp. 373-393). Armonk, N.Y.: M.E. Sharpe.

Lasocki, W. (1933). Wspomnienia z mojego życia (Vol. 1). Kraków.

Liaskoronskiĭ, V. (1908). V. B. Antonovich. (Nekrolog). Zhurnal Ministerstva narodnago prosveshcheniia: New Series, 1908 (part 15), 53-75.

Miiakovs'ky̆ı, V. (1923). V. B. Antonovych: Pered slidchoiu komisiieiu. (Z pryvodu 15 lit smerti V. B. Antonovycha). Chervonyı̆ Shliakh, 1923(3), 234-244.

Miller, A. (2003). The Ukrainian question: The Russian Empire and nationalism in the nineteenth century. Budapest: Central European University Press.

Osnova (Saint Petersburg). (n.d.). Internet Encyclopedia of Ukraine. Retrieved 2 June 2017, from http://www.encyclopediaofukraine.com/display.asp?linkpath=pages $\% 5 C O$ $\%$ 5CS\%5COsnovaSaintPetersburgIT.htm

Padalica, T. [Fisz, Z.]. (1856a). Opowiadania i krajobrazy: Szkice z wędrówek po Ukrainie (Vols. 1-2). Wilno: Nakładem i drukiem Józefa Zawadzkiego.

Padalica, T. [Fisz, Z.]. (1856b). Opowiadania i krajobrazy: Szkice z wedrówek po Ukrainie (Vol. 1). Wilno: Nakładem i drukiem Józefa Zawadzkiego.

Padalica, T. [Fisz, Z.]. (1861). Pan Padalica do pana Vladymyra Antonovycha. Osnova, 1861(10), 136-141.

Plokhy, S. (2005). Unmaking Imperial Russia: Mykhailo Hrushevsky and the writing of Ukrainian history. Toronto: University of Toronto Press. https://doi. org/10.3138/9781442682948

Saunders, D. (1995). Russia and Ukraine under Alexander II: The Value Edict of 1863. The International History Review, 17(1), 23-50. https://doi.org/10.1080/07075332.1995.96 40700

Shevchenko, T. (2003). Zibrannia tvoriv u shesty tomakh (Vol. 1). Kyïv: Naukova dumka.

Ul'ianovs'ky̆ı, V. (1995). Syn Ukraïny (Volodymyr Antonovych: hromadianyn, ucheny̆, liudyna) (pp. 5-76). In V. B. Antonovych, Moja ispovid': Vybrani istorychni ta publitsystychni tvory (F. Ul'ianovs'ky̆, Ed.). Kyïv: Lybid'.

Wiadomości Literackie. (1861). Biblioteka Warszawska, 1861(2), 245-256.

Żochowski, F. (1861). Podobieństwo i różnica języka polskiego z ruskim, czyli wyraźniej z Rusińskim, objawionym w elementarzu wydanym w Wiedniu 1857 roku. Biblioteka Warszawska, 1861(4), 658-671. 